\title{
PENGARUH DAUN TREMBILUNGAN (Begonia hirtella Link) TERHADAP BAKTERI Staphylococcus aureus
}

\author{
${ }^{1}$ Febri Nur Ngazizah \\ ${ }^{1}$ Stikes Borneo Cendekia Medika Pangkalan Bun \\ ${ }^{1}$ Email: febrinurngazizah@gmail.com
}

\begin{abstract}
ABSTRAK
Hampir semua tanaman mengandung senyawa yang dapat digunakan sebagai antibakteri. Salah satu tanaman berkhasiat adalah daun Begonia hirtella yang termasuk suku Begoniaceae dengan ciri tanaman daun asimetris, pada batang terdapat rambut dengan tinggi tanaman sekitar $1 \mathrm{~m}$ dan berumur pendek (Don et al., 2000; Ningsih dan Warsidi, 2013). Penelitian ini bertujuan untuk mengetahui pengaruh ekstrak $n$-heksan, etil asetat dan etanol daun $B$. hirtella terhadap bakteri $S$. aureus dan mengetahui ekstrak yang mempunyai penghambatan yang paling baik terhadap bakteri $S$. aureus Ekstrak adalah sediaan kental yang diperoleh dengan mengekstraksi senyawa aktif dari simplisia nabati dengan menggunakan pelarut yang sesuai, kemudian semua atau hampir semua pelarut diuapkan dan massa atau serbuk yang tersisa diperlakukan sedemikian rupa hingga memenuhi baku yang telah ditetapkan (Badan POM, 2005). Ekstraksi dapat dilakukan dengan metode maserasi. Pelarut yang digunakan dalam ekstraksi antaralain $n$-heksan, etil asetat dan etanol. Heksana Penelitian ini menggunakan metode eksperimental Rancangan Acak Lengkap (RAL), dengan perlakuan uji daya hambat menggunakan ekstrak n-heksan, etil asetat dan etanol konsentrasi 1000 ppm terhadap S. aureus, dengan 4 kali ulangan, diperoleh dari perhitungan menggunakan rumus (Supranto, 2000). Hasil uji aktivitas antibakteri pada bakteri S.aureus, diameter zona hambat kontrol positif ekstrak $n$-heksana sebesar $(11.3 \mathrm{~mm})$, ekstrak etil asetat $(14.3 \mathrm{~mm})$ dan ektrak etanol (12.3 mm). Masing-masing ekstrak mempunyai zona hambat yang berbeda-beda dipengaruhi oleh sifat pelarut dan zat terlarutnya, yang dapat mempengaruhi aktivitas terhadap bakteri uji.
\end{abstract}

Kata Kunci : Simplisia, S. aureus, Zona Hambat 


\title{
THE EFFECT OF TREMBILUNGAN LEAVES (Begonia hirtella Link) ON
}

\section{BACTERIA Staphylococcus aureus}

\begin{abstract}
ABSTRACK
Almost all plants contain compounds that can be used as antibacterial. One of the nutritious plants is Begonia hirtella leaf which belongs to the Begoniaceae tribe with asymmetrical leaf characteristics, on the trunk there is hair with a plant height of about $1 \mathrm{~m}$ and short life (Don et al., 2000; Ningsih and Warsidi, 2013). This study aims to determine the effect of $n$-hexane, ethyl acetate and ethanol extracts of B. hirtella leaves on S. aureus bacteria and determine the extract that has the best inhibition of S. aureus bacteria Extracts are thick preparations obtained by extracting active compounds from simplicia using a suitable solvent, then all or almost all of the solvent is evaporated and the remaining mass or powder is treated in such a way as to meet the established standards (Badan POM, 2005). Extraction can be done by maceration method. The solvent used in the extraction of n-hexane, ethyl acetate and ethanol. Hexane This study used an experimental method with a Completely Randomized Design (CRD), with the inhibitory test treatment using extracts of nhexane, ethyl acetate and ethanol concentration of $1000 \mathrm{ppm}$ against S. aureus, with 4 replications, obtained from calculations using the formula (Supranto, 2000 ). Antibacterial activity test results on $\mathrm{S}$. aureus bacteria, the diameter of the positive control inhibition zone of $n$-hexane extract was $(11.3 \mathrm{~mm})$, ethyl acetate extract (14.3 $\mathrm{mm})$ and ethanol extract $(12.3 \mathrm{~mm})$. Each extract has a different inhibitory zone influenced by the nature of the solvent and its solute, which can affect the activity of the test bacteria.
\end{abstract}

\section{PENDAHULUAN}

Hampir semua tanaman mengandung senyawa yang dapat digunakan sebagai antibakteri. Salah satu tanaman berkhasiat adalah daun Begonia hirtella yang termasuk suku Begoniaceae dengan ciri tanaman daun asimetris, pada batang terdapat rambut dengan tinggi tanaman sekitar $1 \mathrm{~m}$ dan berumur pendek (Don et al., 2000; Ningsih dan Warsidi, 2013).
Daun $B$. hirtella dapat digunakan sebagai antibakteri karena tanaman tersebut mengandung senyawa fenol, flavanoid, steroid, terpenoid dan alkaloid. Senyawa-senyawa yang terkandung dalam suatu tanaman dapat diujikan ke bakteri uji dengan cara ekstraksi dengan pelarut non polar ( $n$ heksan), semi polar (etil asetat) dan polar (etanol). 
Dalam penelitian ini dilakukan metode maserasi dengan cara ekstraksi tunggal masing-masing menggunakan $n$-heksan, etil asetat dan etanol. Maserasi tersebut dimaksudkan untuk menyaring senyawa sesuai dengan tingkat kepolarannya masing-masing, yaitu senyawa non polar seperti steroid dan terpenoid, senyawa semipolar seperti senyawa fenol dan flavanoid serta senyawa polar seperti flavanoid dan alkaloid.

$$
\text { B. hirtella merupakan }
$$
tumbuhan herba, tinggi $3-6 \mathrm{~cm}$, berumah satu, berakar serabut, berumur pendek. Batang hijau atau agak kehijauan, tegak, bercabang, ditutupi rambut yang agak melengkung, terutama pada batang muda. Daun melebar, seperti membrane, bentuk tidak simetris, berbentuk ginjal sampai bulat telur. Buah kapsul, berbentuk oval dan bersayap 3 (Girmansyah, 2014).

Klasifikasi tanaman $B$. hirtella (Hartutiningsih dan Siregar, 2008)

$\begin{array}{ll}\text { Kingdom } & \text { : Plantae } \\ \text { Divisi } & : \text { Spermatophyta }\end{array}$

$\begin{array}{ll}\text { Subdivisi } & : \text { Angiospermae } \\ \text { Kelas } & \text { : Dikotiledoneae } \\ \text { Ordo } & : \text { Cucurbitales } \\ \text { Famili } & : \text { Begoniaceae } \\ \text { Genus } & \text { : Begonia } \\ \text { Spesies } & : \text { Begonia hirtella } \\ \text { Ekstrak } & \end{array}$

Ekstrak adalah sediaan kental yang diperoleh dengan mengekstraksi senyawa aktif dari simplisia nabati dengan menggunakan pelarut yang sesuai, kemudian semua atau hampir semua pelarut diuapkan dan massa atau serbuk yang tersisa diperlakukan sedemikian rupa hingga memenuhi baku yang telah ditetapkan (Badan POM, 2005).

Ekstraksi dapat dilakukan dengan metode maserasi. Proses maserasi dilakukan dengan merendam simplisia ke dalam pelarut tanda proses pemanasan. Pelarut yang digunakan dalam ekstraksi antaralain $n$-heksan, etil asetat dan etanol. Heksana adalah sebuah senyawa hidrokarbon alkana dengan rumus kimia $\mathrm{C}_{6} \mathrm{H}_{14} . n$-heksana bersifat nonpolar memiliki kemampuan untuk megikat gugus nonpolar. Etil asetat merupakan jenis pelarut yang bersifat semi polar. Pelarut ini memiliki titik didih yang relatif rendah yaitu $77^{\circ} \mathrm{C}$. Etanol disebut juga etil alkohol 
yang di pasaran lebih dikenal sebagai alkohol merupakan senyawa organik

Suarsa dan Kurniawati 2011; Susanti et al., 2012).

\section{Staphylococcus aureus}

S. aureus adalah bakteri berbentuk bulat dengan susunan sel membentuk seperti buah anggur, pada kondisi tertentu dapat mempunyai susunan satu-satu, berpasangan atau dalam bentuk rantai pendek (Iskamto, 2009). Bersifat fakultatif anaerobik yaitu dapat tumbuh bila ada atau tidak ada oksigen (Waluyo, 2005).

S. aureus adalah bakteri normal pada mulut, saluran pernafasan atas, usus besar dan kulit pada manusia. Infeksi di dalam tubuh biasanya terjadi jika kekebalan tubuh melemah akibat adanya perubahan hormon, adanya penyakit, luka dan konsumsi obat antiradang (steroid) yang melemahkan daya tahan tubuh (Utami, 2012).

\section{METODOLOGI PENELITIAN}

$\underline{\text { Alat }}$

Alat yang digunakan dalam penelitian yaitu: autoklaf, Laminar air flow, rotary evaporatory (Stuart), hot plate (Stuart), gunting, ember, nampan aluminium, blender, saringan ukuran 60 mesh, beaker dengan rumus kimia $\mathrm{C}_{2} \mathrm{H}_{5} \mathrm{OH}$.

(Munawaroh dan Handayani, 2010

glass $1000 \mathrm{ml}$, timbangan analitik, labu Erlenmeyer, spidol, buku tulis, tabung reaksi, rak tabung reaksi, pipet ukur, pipet tetes, vortex, stirrer, gelas ukur, karet gelang, lampu bunsen, korek api, masker, handstool, ose bulat, oven, petri dish, mikropipet, yellow tip, drugalsky, kertas cakram $6 \mathrm{~mm}$, kamera, penggaris, panci.

\section{Bahan}

Bahan yang digunakan dalam penelitian meliputi:

\section{Pembuatan ekstrak}

Plastik bening ukuran $2 \mathrm{~kg}$, daun Begonia hirtella yang tumbuh di Desa Kalisat kidul Kec. Kalibening Kab. Banjarnegara, etil asetat, aquades, kertas saring, Sulfoxide dimetil (DMSO) 5\%, aluminium foil, wrapping, kertas label dan kertas tisu.

\section{Uji antimikroba}

Bubuk Nutrient Agar (NA), bubuk Nutrient Broth (NB), biakan S. aureus, yang diperoleh dari Laboratorium Mikrobiologi

Fakultas Biologi Universitas Jenderal Soedirman. 
$\mathrm{m}=S$. aureus

\section{Rancangan Penelitian}

Penelitian ini menggunakan metode eksperimental Rancangan Acak Lengkap (RAL), dengan perlakuan uji daya hambat menggunakan ekstrak nheksan, etil asetat dan etanol konsentrasi $1000 \mathrm{ppm}$ terhadap $S$. aureus, dengan 4 kali ulangan, diperoleh dari perhitungan menggunakan rumus (Supranto, 2000). $(\mathrm{n}-1)(\mathrm{t}-1) \geq 15$ $(\mathrm{n}-1)(3-1) \geq 15$ $(\mathrm{n}-1)(2) \geq 15$

$2 \mathrm{n}-2 \geq 15$

$2 \mathrm{n} \geq 15+2$

$2 \mathrm{n} \geq 17$

$\mathrm{n} \geq 17 / 2$

$\mathrm{n} \geq 9$

sehingga terdapat 18 unit percobaan. Masing-masing perlakuan tersebut adalah sebagai berikut:

E1m= uji ekstrak $n$-heksan terhadap $S$. aureus

E2m= uji ekstrak etil asetat terhadap $S$. aureus

E3m= uji ekstrak etanol terhadap $S$. aureus

Keterangan:

$\mathrm{E} 1=$ ekstrak $n$-heksan

$\mathrm{E} 2=$ ekstrak etil asetat

$\mathrm{E} 3=$ ekstrak etanol

\section{HASIL DAN PEMBAHASAN}

Daun B. hirtella yang berwarna hijau diambil di ladang di daerah Kec. Kalibening sampel dikumpulkan sebanyak $3 \mathrm{~kg}$ kemudian dibersihkan dengan menggunakan air mengalir bersih kemudian dikeringkan dengan cara diangin-anginkan. Pengeringan bertujuan untuk menurunkan aktivitas kadar air dalam bahan sehingga mikroorganisme penyebab kerusakan bahan tidak dapat hidup dan dapat disimpan dalam jangka waktu yang lebih lama. Simplisia yang telah kering diserbukkan dengan menggunakan blender, kemudian diayak dengan menggunakan ayakan mesh 60 hingga diperoleh serbuk yang halus. Pembuatan serbuk bertujuan untuk memperluas permukaan yang berinteraksi dengan pelarut sehingga lebih banyak senyawa yang dapat terekstrak.

Metode yang digunakan dalam pembuatan ekstrak daun $B$. hirtella dilakukan dengan metode maserasi. Metode maserasi ini mempunyai beberapa kelebihan diantaranya cara pengerjaan dan peralatan yang digunakan sederhana dan tidak 
merusak senyawa yang tidak tahan panas. Pelarut untuk ekstraksi mempunyai kepolaran yang sama dengan senyawa yang akan diambil. Hal ini disebabkan kandungan kimia dari suatu tumbuhan hanya dapat larut dalam pelarut yang sama kepolarannya. Pemilihan pelarut ekstraksi didasarkan pada prinsip like dissolved like yaitu senyawa polar akan cenderung larut pada pelarut polar dan senyawa non polar akan cenderung larut pada pelarut non polar, sehingga $n$-heksana akan melarutkan senyawa non polar, etil asetat akan melarutkan senyawa semi polar, dan etanol akan melarutkan senyawa polar.

Simplisia daun B. hirtella diekstraksi menggunakan masingmasing pelarut selama 5 hari, dan dilakukan pengulangan dengan penggantian pelarut selama 2 hari, bertujuan untuk mengekstrak seluruh senyawa kimia yang ada dalam sampel (Moningka, 2015). Selanjutnya hasil rendaman dilakukan pemisahan yang terdiri dari penyaringan dan evaporasi. Penyaringan dilakukan untuk memisahkan sampel dengan pelarut yang telah mengandung bahan aktif. Pemisahan pelarut dengan senyawa bioaktif yang terikat dilakukan evaporasi menggunakan rotary evaporator. Sehingga didapatkan ekstrak kental bebas pelarut yang siap digunakan untuk uji antibakteri terhadap S. aureus.

\section{Uji Aktivitas Antibakteri}

Uji aktivitas antibakteri ekstrak $n$-heksana, etil asetat dan etanol daun B. hirtella terhadap bakteri S. aureus menggunakan metode difusi agar Kirby Bauer. Pengujian menggunakan kertas cakram berdiameter $6 \mathrm{~mm}$ yang telah disterilkan terlebih dahulu dan setiap kertas cakram diresapi sebanyak $50 \mu \mathrm{L}$ larutan uji/ekstrak dengan berbagai pelarut konsentrasi 1000 ppm. Zona hambat yang terbentuk diidentifikasi dengan melihat daerah bening di sekeliling cakram dan besarnya zona hambat diketahui berdasarkan pengukuran diameter daerah bening tersebut.

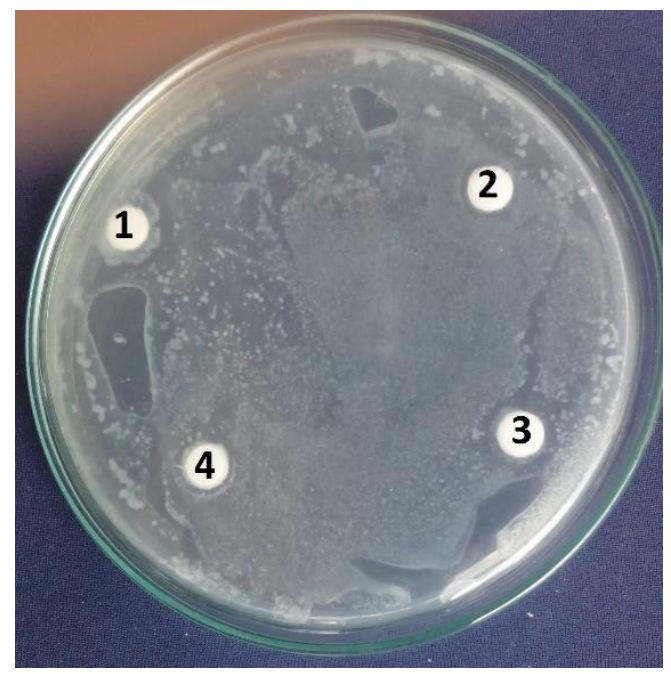


Gambar Zona hambat ujiantibakteri 1. kontrol negatif 2. ekstrak n-heksan 3. ekstrak etil asetat 4. ekstrak etanol terhadap bakteri S.aureus

Gambar tersebut menunjukkan pada kontrol negatif tidak membentuk zona hambat. Kontrol negatif uji aktivitas antimikroba menggunakan DMSO 5\%. DMSO adalah senyawa organosulfur dengan rumus $\left(\mathrm{CH}_{3}\right)_{2} \mathrm{SO}$. Cairan tidak berwarna ini merupakan pelarut polar aprotik yang dapat melarutkan senyawa polar, nonpolar dan larut dalam berbagai pelarut organik maupun air (Badan POM, 2010). DMSO dipakai karena kemampuan difusi DMSO yang baik pada media agar dan tidak memberikan daya hambat (Purwanti et al., 2014).

Kontrol negatif menggunakan DMSO, karena DMSO digunakan untuk melarutkan ekstrak. Hasil uji antimikroba menunjukkan bahwa DMSO tidak membentuk zona hambat. Hal ini menunjukkan bahwa zona hambat yang terbentuk pada perlakuan berasal dari ekstrak uji, tidak dipengaruhi oleh DMSO.

Hasil pengukuran diameter zona hambat masing-masing ekstrak terhadap bakteri S.aureus dapat dilihat pada Tabel 1

Tabel 1 Hasil pengukuran diameter zona hambat ekstrak $n$-heksana, etil asetat dan etanol daun B. hirtella terhadap bakteri Staphylococcus aureus

\begin{tabular}{|c|c|c|c|}
\hline \multirow{2}{*}{ Pengulangan } & \multicolumn{3}{|c|}{ Diameter zona hambat (mm) } \\
\cline { 2 - 4 } & Ekstrak $n$ - heksan & Ekstrak etil asetat & Ekstrak etanol \\
\hline 1 & 12 & 15 & 13 \\
\hline 2 & 10 & 14 & 12 \\
\hline 3 & 12 & 15 & 13 \\
\hline 4 & 11 & 14 & 11 \\
\hline 5 & 12 & 13 & 13 \\
\hline 6 & 12 & 12 & 13 \\
\hline 7 & 11 & 16 & 11 \\
\hline 8 & 10 & 15 & 12.3 \\
\hline 9 & 12 & 15 & 13.3 \\
\hline Rata-rata & 11.3 & & 13 \\
\hline
\end{tabular}


Hasil uji aktivitas antibakteri pada bakteri S.aureus, diameter zona hambat kontrol positif ekstrak nheksana sebesar $(11.3 \mathrm{~mm})$, ekstrak etil asetat $(14.3 \mathrm{~mm})$ dan ektrak etanol (12.3 mm). Masing-masing ekstrak mempunyai zona hambat yang berbeda-beda dipengaruhi oleh sifat pelarut dan zat terlarutnya, yang dapat mempengaruhi aktivitas terhadap bakteri uji.

\section{Ekstrak}

$n$-heksana

menunjukkan adanya aktivitas antibakteri yang paling kecil dibandingkan dengan ekstrak lain. Hal ini disebabkan karena ekstrak nheksana melarutkan senyawa minyak. Senyawa minyak atsiri dan lipida lainnya mempunyai ukuran molekul besar tidak dapat masuk berpenetrasi ke dalam dinding sel bakteri. Ukuran molekul besar tersebut akan menjadi penghalang masuknya komponen minyak atsiri maupun senyawa fenolik ke dalam sel akibatnya sel tetap akan tumbuh Kanazawa et al.(1995); Moningka et al. (2015)

Hasil penelitian menunjukkan ekstrak etanol mempunyai zona hambat yang lebih besar dibandingkan ekstrak n-heksan. Menurut Rahminiwati et al., (2011) ektrak etanol dimaksudkan agar semua senyawa kimia baik yang kurang polar, semi polar sampai polar dapat terekstraksi semaksimal mungkin.

Ekstrak etil asetat membentuk zona hambat terbesar karena etil asetat mengandung senyawa antimikroba yang mampu menghambat atau membunuh mikroba lebih tinggi dibandingkan ekstrak yang lainnya. Fitrial et al. (2008) menyatakan senyawa semipolar mempunyai afinitas lebih tinggi untuk berinteraksi dengan diding sel, sehingga ekstrak semipolar lebih efektif menghambat pertumbuhan bakteri daripada ekstrak etanol, air (polar) dan ekstrak heksan (non polar).

\section{KESIMPULAN DAN SARAN}

Berdasarkan penelitian dapat disimpulkan bahwa:

1. Jenis pelarut ekstrak $n$-heksan, etil asetat dan etanol daun $B$. hirtella berpengaruh terhadap zona hambat bakteri $S$. aureus

2. Pelarut yang mempunyai penghambatan terbaik adalah ekstrak etil asetat

Pada penelitian selanjutnya perlu dilakukan penelitian lebih lanjut mengenai: 
1. Mikroba yang digunakan untuk uji lebih bervariasi

2. Dilakukan uji senyawa ekstrak etil asetat daun $B$. hirtella yang diduga berperan sebagai antibakteri S.aureus

\section{DAFTAR PUSTAKA}

Anonim. 2016. Australian Tropical Rainforest Plant. (On-line), http:// keys.trin.org.au/ keyserver/ data/0e0f0504 -0103430d- 8004060d07080d04/media/Html/ta xon/ Begonia hirtella.htm diakses 8 Februari 2016.

Badan POM, 2005. Info POM: Standarisasi Ekstrak Tumbuhan Obat Indonesia, Salah satu Tahapan Penting Dalam Pengembangan Obat Asli Indonesia. Direkotat Obat Asli Indonesia, Jakarta.

- 2010. Acuan Sediaan Herbal. Direkotat Obat Asli Indonesia, Jakarta

Fadhilah, H., H. Rivai dan R. Yuandina. 2014. Pembuatan dan Karakterisasi Ekstrak Kering Daun Jambu Mete (Anacardium occidentale L.). Prosiding Seminar Nasional dan Workshop "Perkembangan Terkini Sains Farmasi dan Klinik $I V$ ', Padang.

Fitrial, Y., M. Astawan, S. S. Soekarto, K. G. Wiryawan, T. Wresdiyati dan R. Khairina. 2008. Antibakteri Ekstrak Biji Teratai (Nymphaea pubescens Wild) terhadap Bakteri Patogen Penyebab Diare. Jurnal Teknologi dan Industri Pangan. 19 (2): 158164.

Girmansyah, D. 2014. Begonia hirtella Link di Jawa. LIPI: Cibinong Bogor.

Hartutiningsih dan M. Siregar. 2008. Mengenal dan merawat Begonia. PT Agro Media Pustaka, Jakarta.

Iskamto, B. 2009. Bakteriologi Kesehatan. UNS Press, Surakarta.

Moningka, K. C., N. S. Kojong dan S. Sudewi. 2015. Uji Aktivitas Antibakteri Ekstrak Daun Ekor Kucing (Acalypha hispida Burm. F.) terhadap Bakteri Staphylococcus aureus dan Escherichia coli secara In-Vitro. 4 (3): 193202.

Ningsih, M. L. dan Warsidi. 2013. Aplikasi Hormon Tumbuh Pada Perbanyakan Tanaman Begonia Melalui Setek Daun dan Setek Irisan Daun. Balai Penelitian Teknologi Pembenihan, Balikpapan.

Prawira, M. Y., Sarwiyono dan P. Surjowardojo. 2013. Daya Hambat Dekok Daun Kersen (Muntingia calabura L.) terhadap Pertumbuhan Bakteri Staphylococcus aureus Penyebab Penyakit Mastitis pada Sapi Perah. Universitas Brawijaya, Malang. 
Purwanti, L., A. Maharani dan L.

Syafnir. 2014. Uji Aktivitas

Antibakteri dan Isolasi

Alkaloid dalam Daun Tomat

(Lycopersicon esculentum

Mill.). Prosiding Seminar

Nasional Penelitian dan PKM

Sains, Teknologi dan

Kesehatan, Unisba.

Rahminiwati, M., I. Juwita, A.

Murtisari dan L. K.

Darusman. 2011. Aktivitas

Ekstrak Temulawak

(Curcuma Xanthorrhiza

Roxb.) terhadap Proliferasi

dan Diferensiasi Sel Otak

Besar Anak Tikus Berumur

Tiga Hari secara In Vitro.

Fitofarmaka. 1 (2): 1-8.

Supranto, J. 2000. Statistik Teori dan Aplikasi. Jilid 1 Edisi 6. Erlangga, Jakarta.

Susanti, A. D., D. Ardiana, G. P. Gumelar dan Y. Bening. 2012. Polaritas Pelarut sebagai Pertimbangan dalam Pemilihan Pelarut untuk Ekstraksi Minyak Bekatul dari Bekatul Varietas Ketan (Oriza sativa glatinosa). Simposium Nasional RAPI XI FT UMS, Surakarta.

Utami, P. 2012. Antibiotik Alami untuk Mengatasi Aneka Penyakit. AfroMedia Pustaka, Jakarta.

Waluyo, L. 2005. Mikrobiologi Lingkungan. UMM Press, Malang. 